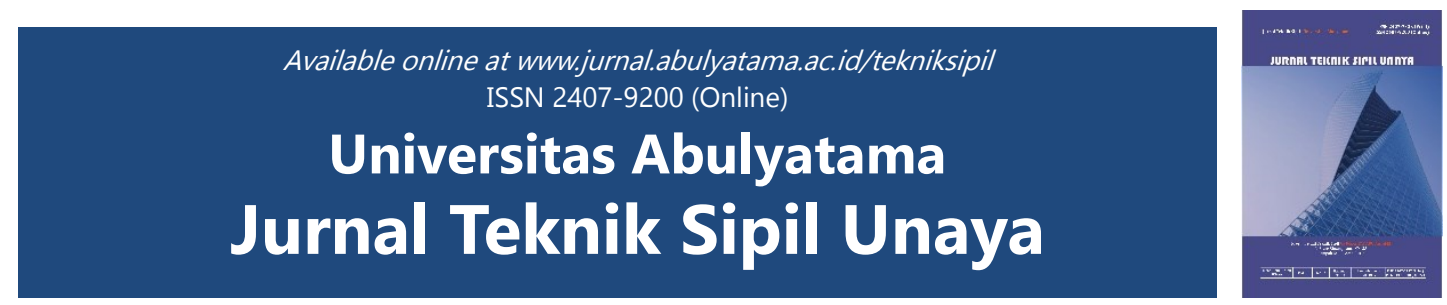

\title{
Persepsi dan Motivasi Dalam Memilih Perumahan (Studi Kasus: Perumahan Villa Citra dan Villa Buana Garden)
}

\author{
Edi Mawardi ${ }^{1^{*}}$, Rinaldy ${ }^{1}$ \\ ${ }^{1}$ Program Studi Teknik Sipil, Fakultas Teknik, Universitas Teuku Umar, Jl. Alue Peunyareng, \\ Kec. Meureubo Kab. Aceh Barat, 23681, Indonesia \\ *Email korespondensi : edimawardi@utu.ac.id.
}

Diterima 2 Maret 2019; Disetujui 2 Juni 2019; Dipublikasi 31 Juli 2019

\begin{abstract}
In addition to being the center of Aceh's administrative administration, Banda Aceh is also the center of economic, educational and trade activities, so that economic growth and the population grow rapidly. Consumer factors in choosing housing vary greatly, because each individual has different desires in choosing the desired housing. The purpose of this study is to find out consumer factors in choosing and determining the desired housing. Based on the theories and views outlined, a resume can be made about consumer preferences in choosing and determining residence/housing. The results of the conclusion analysis of 100 respondents kept Villa Citra housing $39.02 \%$ age $<30$ years and $26.83 \%$ aged $>51$ years while in Villa Buana housing $42.37 \%$ were aged 31-40 years. The two houses were complying with the Bachelor degree educational background, namely: $60.98 \%$ Villa Citra and 67.80\% Villa Buana. analysis that $43.90 \%$ earned IDR 1,000,000 - 2,500,000 chose Villa Citra housing because of the influence of the distance to the city center of about 3.5 Kilometers. while Villa Buana reached $61.02 \%$ with an income of IDR 2,500,001 - 4,000,000 with an urban center of around 5.5 Kilometers.
\end{abstract}

Keywords: Banda Aceh, Motivation, Housing

\begin{abstract}
Abstrak: Kota Banda Aceh selain sebagai pusat administrasi pemerintahan Aceh, juga merupakan pusat kegiatan ekonomi, pendidikan serta kegiatan perdagangan, sehingga pertumbuhan ekonomi dan jumlah penduduk tumbuh dengan pesat. Faktor konsumen dalam memilih perumahan sangat bervariasi, karena setiap individu mempunyai keinginan berbeda-beda dalam memilih perumahan yang diinginkan. Tujuan dari penelitian ini yaitu untuk mengetahui faktor konsumen dalam memilih dan menentukan perumahan yang diinginkan. Berdasarkan teori-teori dan pandangan yang diuraikan, maka dapat dibuat suatu resume tentang preferensi konsumen dalam memilih dan menetukan tempat tinggal/perumahan. Hasil analisa disimpulan dari 100 responden menepati perumahan Villa Citra $39,02 \%$ usia $<30$ Tahun dan 26,83\% usia $>51$ tahun sedangkan di perumahan Villa Buana 42,37\% ditempati usia 31 - 40 Tahun. Kedua perumahan tersebut yang menepati latar belakang pendidikan D3/S1 yaitu: 60,98\% Villa Citra dan 67,80\% Villa Buana. analisa bahwa 43,90\% penghasilan Rp. $1.000 .000-2.500 .000$ memilih perumahan Villa Citra karena pegaruh faktor jarak dengan pusat Perkota sekitar 3,5 km. sedangkan Villa Buana mencapai 61,02\% ditempati penghasilan Rp. 2.500.001- 4.000.000 jarak dengan pusat Perkotaan sekitar 5,5 Km.
\end{abstract}

Kata kunci : Banda Aceh, Motivasi, Perumahan 
Ibu kota provinsi Aceh selain sebagai pusat administrasi pemerintahan Aceh, juga merupakan pusat kegiatan ekonomi, pendidikan serta kegiatan perdagangan, sehingga pertumbuhan ekonomi dan jumlah penduduk tumbuh dengan pesat. Berdasarkan latar belakang dan permasalahan tersebut di atas maka dilakukan penelitian untuk mencari persepsi dan motivasi konsumen dalam memilih perumahan.

Tujuan dari penelitian ini yaitu untuk mengetahui factor-faktor dalam memilih dan menentukan perumahan yang diinginkan serta untuk mengetahui faktor dominan yang paling berpengaruh bagi konsumen dalam memilih dan menentukan konsep perumahan. Manfaat dari penelitian ini untuk mengetahui informasi factorfaktor yang paling pengaruh bagi pihak pengembang perumahan maupun pihak pemerintah supaya lebih terarah dan mengurangi kesenjangan antara konsumen dengan konsep perumahan yang dibangun oleh pengembang khususnya untuk konsumen baru di Kota Banda Aceh.

\section{KAJIAN PUSTAKA}

\section{Definisi Konsumen}

Suryani, (2008) Konsumen adalah setiap orang pemakai barang dan/atau jasa yang tersedia dalam masyarakat, baik bagi kepentingan diri sendiri, keluarga, orang lain, maupun makhluk hidup lain dan tidak untuk diperdagangkan.

\section{Definisi Perumahan}

Catanese \& Snyder (1996), menyatakan bahwa secara tradisional perumahan diartikan sebagai tempat berlindung, tapi secara modern selain digunakan sebagai tempat berlindung, perumahan juga digunakan sebagai tempat untuk melayani berbagai kebutuhan seperti memasak, makan, bekerja, tidur dan rekreasi. Perumahan merupakan tempat bermukim dan pintu masuk ke dunia yang menjanjikan pemenuhan kebutuhan dasar lainnya.

\section{Faktor Karakteristik Individu}

Individu memperoleh pengetahuan tentang suatu tempat dari persepsi dan interaksi dengan individu lainnya. Informasi yang didapat ini setelah melalui proses didalam setiap individu ini kemudian membentuk kelompok dan kelompok ini membentuk berbagai variasi bentuk cluster dari individu-individu yang mempunyai persamaan dalam ekonomi, sosial, politik serta pandangan atau referensi tentang tempat tinggalnya. Karakteristik ruang sosial dari suatu kota dan ekspresi dari lingkungan sangat menentukan didalam pemilihan lokasi tempat tinggalnya. Kerangka dari referensi ini merupakan hasil dari beberapa faktor termasuk usia, latar belakang sosial, kepercayaan (agama) dan latar belakang etnis (Golledge \& Stimson, 1987).

\section{Faktor Karakteristik Rumah Tangga}

Model tingkah laku rumah tangga dalam memilih lokasi tempat tinggalnya diklasifikasikan menjadi 2 (dua) kategori dasar :

a. Asumsi Pertama : Pilihan lokasi tempat tinggal dapat dijelaskan dalam pengertian "trade of" antara biaya transportasi dan harga rumah. 
b. Asumsi Kedua : Model prilaku mikro, yaitu aksesibilitas bukan syarat utama dalam pemilihan lokasi tempat tinggal, tetapi kenyamanan lingkungan, sosial ekonomi, psikologi dan waktu. Faktorfaktor ini bekerjasama menghasilkan bermacam-macam penjelasan tentang pembuatan keputusan. Pendekatan perilaku ini memberikan tekanan pada saat keputusan pemilihan lokasi ini dibuat (Ibid, dalam Nurhadi, 2004).

\section{Faktor Karakteristik Keluarga}

Menurut Morris \& Winter, (1978), faktor lain yang ikut memberikan rasa terhadap tempat tinggal adalah faktor fisik lingkungan. Sedangkan faktor-faktor yang melatarbelakangi kepuasan terhadap tempat tinggal adalah :

1. Demografi dan sosial ekonomi (meliputi tingkat kehidupan, status ekonomi dan struktur keluarga);

2. Ketidakpuasan terhadap tempat tinggal lama;

3. Pengaruh dari kondisi perumahan, tetangga dan lingkungan ditempat yang baru.

Hubungan dari ketiga faktor tersebut dapat dilihat pada Gambar 2.3 berikut.

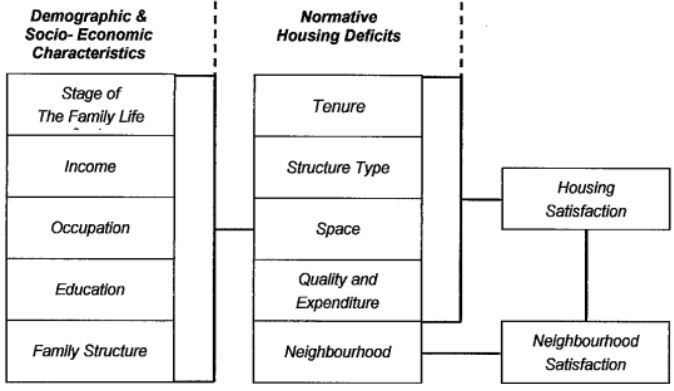

Sumber : Morris \& Winter, 1978

Gambar 2.3 Hubungan Faktor yang Mempengaruhi Kepuasan Tempat Tinggal

\section{Faktor Status Sosial Ekonomi}

Roistacher (1977), menerangkan tentang hubungan antara pendapatan berhubungan langsung dengan mobilitas. Perpindahan berarti penyesuaian perumahan dengan status ekonomi. Kenaikan pendapatan memberikan efek langsung terhadap perpindahan untuk mendapatkan rumah yang lebih baik. Hubungan antara mobilitas sosial secara vertikal dengan perpindahan rumah merupakan kebutuhan untuk memenuhi prestige, yaitu bahwa perpindahan terjadi jika terdapat kenaikan pendapatan keluarga. Bertambahnya pendapatan akan mengubah preferensi keluarga terhadap kualitas lingkungan.

Reksohadiprodjo dan Karseno, (1997) menyatakan bahwa Preferensi perumahan akan cenderung lebih dikaitkan dengan tingkat pendapatan dan lokasi perumahan menurut masyarakat sebagai konsumen. Keterkaitan tersebut dapat diilustrasikan seperti berikut:

- Banyak masyarakat kota yang berpenghasilan tinggi akan menyebabkan permintaan yang tinggi atas rumah. Umumnya mereka akan memilih lokasi diluar kota; 
- Masyarakat yang berpenghasilan rendah lebih cenderung bermukim didalam atau didekat kota.

\section{Faktor-faktor Referensi Konsumen dalam}

\section{Memilih Perumahan}

Berdasarkan teori-teori dan pandangan yang telah diuraikan, maka dapat dibuat suatu resume tentang preferensi konsumen dalam memilih dan menetukan tempat tinggal/perumahan. Preferensi tersebut dapat dibentuk dari 2 (dua) faktor umum yaitu faktor internal dan faktor eksternal. Adapun faktor-faktor preferensi konsumen dalam memilih perumahan berdasarkan teori-teori yang telah diuraikan sebelumnya dapat dilihat pada tabel 2.1 berikut ini:

\section{Tabel 2.1Teori Pemilihan Lokasi Perumahan}

\begin{tabular}{|c|c|c|}
\hline Faktor Internal & Faktor Eksternal & Referensi \\
\hline $\begin{array}{l}\text { - } \text { Biaya hidup } \\
\text { langsung/tidak } \\
\text { langsung. }\end{array}$ & $\begin{array}{l}\text { - Kondisi fisik } \\
\text { bangunan; } \\
\text { - Lokasi; } \\
\text { - Suasana } \\
\text { lingkungan; } \\
\text { - Tetangga } \\
\text { sekitar; } \\
\text { - Fasilitas dan } \\
\text { Pelayanan sosial }\end{array}$ & $\begin{array}{l}\text { - Budihardjo, } \\
1998\end{array}$ \\
\hline $\begin{array}{l}\text { - Usia; } \\
\text { - Latar belakang } \\
\text { sosial; } \\
\text { - Kepercayaan } \\
\text { (Agama); } \\
\text { - Etnis. }\end{array}$ & $\begin{array}{l}\text { - Kenyamanan } \\
\text { lingkungan; } \\
\text { - Aksesibilitas. }\end{array}$ & $\begin{array}{l}\text { - Golledge \& } \\
\text { Stimson, } \\
1987 .\end{array}$ \\
\hline $\begin{array}{l}\text { Sosial - } \\
\text { Ekonomi; }\end{array}$ & $\begin{array}{l}\text { - Fisik } \\
\text { lingkungan; } \\
\text { - Kelas sosial - } \\
\text { Etnis. }\end{array}$ & $\begin{array}{l}\text { Yeaters \& } \\
\text { Garner, } \\
1980 .\end{array}$ \\
\hline $\begin{array}{l}\text { - Demografi; } \\
\text { - Sosial - } \\
\text { Ekonomi. }\end{array}$ & $\begin{array}{l}\text { - Ketidakpuasan } \\
\text { terhadap tempat } \\
\text { tinggal lama; } \\
\text { - Pengaruh dari } \\
\text { kondisi } \\
\text { perumahan. }\end{array}$ & $\begin{array}{l}\text { - Morris \& } \\
\text { Winter, } \\
1978 .\end{array}$ \\
\hline - Pendapatan. & $\begin{array}{l}\text { - Fasilitas sosial } \\
\text { dan } \\
\text { Kenyamanan; } \\
\text { - Lokasi dekat } \\
\text { dengan tempat } \\
\text { kerja; } \\
\text { - Status } \\
\text { kepemilikan; } \\
\text { - Standar rumah } \\
\text { modern. }\end{array}$ & $\begin{array}{l}\text { - Roistacher, } \\
\text { 1977; } \\
\text { - Reksohadip } \\
\text { rojo \& } \\
\text { Karseno, } \\
1997 ; \\
\text { - Turner, } \\
\text { 1982; } \\
\text { - Burgess } \\
\text { dalam } \\
\text { Daldjoeni, }\end{array}$ \\
\hline
\end{tabular}

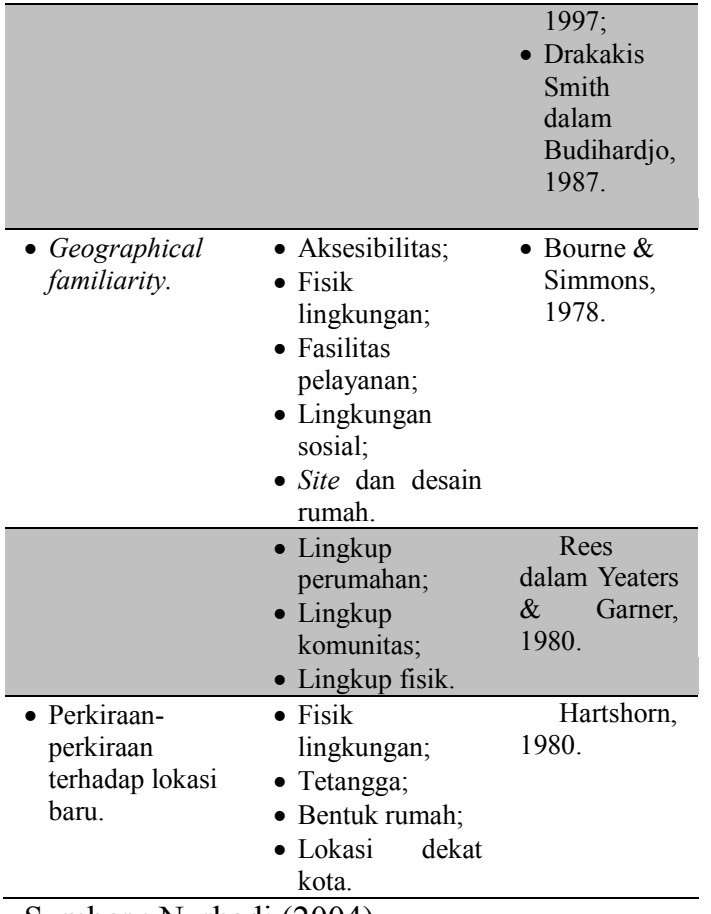

Sumber : Nurhadi (2004)

\section{METODE PENELITIAN}

Dalam penelitian ini, lokasi yang akan menjadi tempat pengambilan sampel untuk data penelitian dibatasi pada dua lokasi komplek perumahan yang ada dalam wilayah Kota Banda Aceh maupun lokasi berbatasan dengan Kabupaten Aceh Besar. Lokasi perumahan ini memiliki jarak yang berbeda terhadap pusat Kota Banda Aceh. Lokasi pengambilan data dalam penelitian ini adalah sebagai berikut.

1. Perumahan Villa Citra;

Perumahan Villa Citra ini terletak di Gampong Pineung, Kecamatan Syiah Kuala. Berdasarkan data hasil survei awal ke lokasi, Jarak perumahan ini terhadap pusat Kota Banda Aceh adalah lebih kurang 3.5 kilometer. Perumahan ini dibangun oleh pengembang perumahan PT. Bumi Aceh Lestari pada tahun 2001. Pada komplek perumahan ini terdapat rumah sebanyak 140 
unit dengan dengan beberapa tipe dasar yaitu tipe 36, tipe 45, tipe dan 60. Luas kapling tanah rata-rata 170 sampai dengan 200 meter persegi.

2. Perumahan Villa Buana Gardenia;

Perumahan Villa Buana Gardenia ini terletak di Gampong Lampasie Engking, Kecamatan Darul Imarah Kabupaten Aceh Besar. Berdasarkan data hasil survey awal ke lokasi, Jarak perumahan ini terhadap pusat Kota Banda Aceh adalah lebih kurang 5,5 kilometer. Perumahan ini dibangun oleh pengembang perumahan PT. Bumi Aceh Lestari tahun 2000. Pada komplek perumahan ini terdapat rumah sebanyak 200 unit dengan dengan beberapa tipe dasar yaitu tipe 36 tipe 45 , tipe 54 dan tipe 70 . Luas kapling tanah rata-rata 170 sampai dengan 240 meter persegi.

\section{Sumber dan Proses Pengumpulan Data}

Data yang diperlukan dalam penelitian ini meliputi data primer dan data sekunder. Data primer berupa data preferensi konsumen Kota Banda Aceh maupun di Aceh Besar.

Data primer adalah data yang didapat langsung dari responden (konsumen atau penghuni perumahan).

Data sekunder yang diperlukan dalam penelitian ini berupa peta Kota Banda Aceh, peta komplek perumahan yang dijadikan lokasi penelitian, jumlah rumah dan kepala keluarga serta data lainnya yang diperlukan dalam penelitian.

\section{Teknik Sampling}

Teknik sampling yang digunakan dalam penelitian ini adalah teknik simple random sampling, dimana pengambilan sampel dari populasi dilakukan secara acak sehingga setiap sampel memiliki peluang yang sama untuk dipilih.

\section{Penentuan Jumlah Sampel}

Responden dalam penelitian ini adalah konsumen perumahan yang tinggal di komplek Perumahan yaitu Perumahan Villa Citra Gampong Pineung Kecamatan Syiah Kuala dan Perumahan Villa Buana Gardenia Gampong Lampasie Engking Kecamatan Darul Imarah Kabupaten Aceh Besar. Dari data hasil survei pada dua lokasi perumahan tersebut diperoleh bahwa jumlah rumah pada perumahan Villa Citra sebanyak 140 unit dan Villa Buana Gardenia sebanyak 200 unit.

\section{Rancangan Kuesioner}

Kuesioner dirancang berdasarkan teori serta asumsi yang relevan dengan penelitian. Kuesioner disebarkan kepada responden yang merupakan konsumen atau penghuni perumahan. Responden ini merupakan Kepala Keluarga pada masing-masing rumah pada perumahan yang diteliti. Kuesioner yang diajukan berisi beberapa pertanyaan dengan sistem tertutup. Setelah kuesioner dikumpulkan, hasil jawabannya akan direkapitulasi dengan menggunakan skala likert.

\section{Metode Analisis}

Metode analisis yang digunakan, dipisahkan untuk tahap pertama dan tahap kedua penelitian. Pada tahap pertama data yang 
diperoleh diperlakukan sebagai data kuantitatif.

Adapun langkah-langkah analisis dalam penelitian ini adalah sebagai berikut: Memberikan gambaran mengenai identitas responden dalam penelitian ini, sebab dengan menguraikan identitas responden yang menjadi sampel dalam penelitian ini maka akan dapat diketahui sejauh mana identitas responden dalam penelitian ini. Oleh karena itulah deskripsi identitas responden dalam penelitian ini dapat dikelompokkan menjadi beberapa kelompok yaitu : jenis kelamin, tingkat pendidikan, jenis pekerjaan dan usia responden.

\section{HASIL DAN PEMBAHASAN}

\section{Karakteristik Responden}

Dalam gambaran umum karakteristik responden ini akan disajikan data yang diperoleh dari penelitian yang telah dilakukan. Pengumpulan data ini dilakukan dengan cara penyebaran kuesioner kepada 100 responden secara acak, uraian karakteristik respendon adalah sebagai berikut:

\section{Deskripsi Responden Berdasarkan Usia/Umur}

Deskripsi responden berdasarkan usia dapat dilihat pada Gambar 1 berikut:

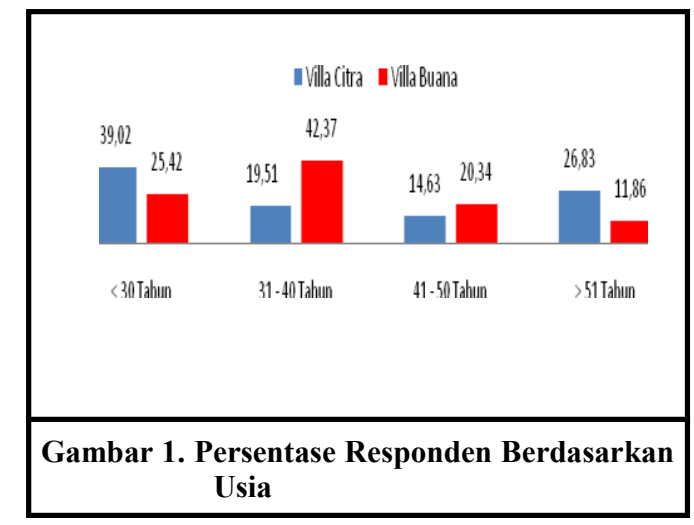

Berdasarkan Gambar 1 dari hasil penelitian responden berusia $<30$ Tahun sebanyak 39,02\% sedangkan pada Villa Buana Gardenia yang paling banyak yaitu responden yang berusia 31 40 Tahun.

\section{Deskripsi Responden Berdasarkan Pendidikan}

Deskripsi responden berdasarkan Pendidikan dapat dilihat pada Gambar 2 berikut :

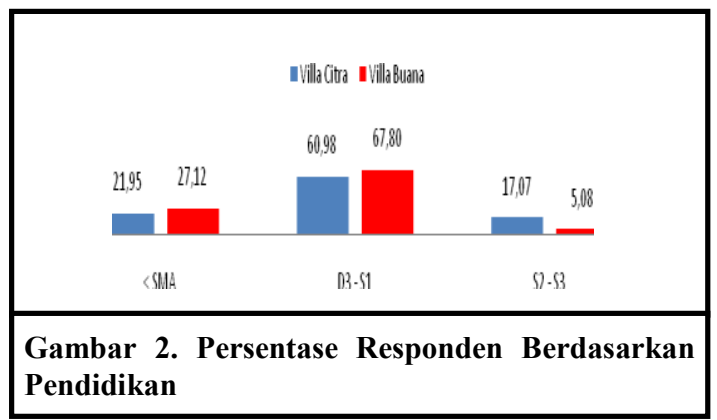

Berdasarkan Gambar 2. dapat diketahui dari 100 responden pada Villa Buana sebanyak $67,80 \%$ yang paling banyak berpendidikan D3 - S1, begitu juga dengan Villa Citra sebanyak 60,98 \% dengan berpendidikan D3 $-\mathrm{S} 1$.

\section{Deskripsi Responden Berdasarkan Pekerjaan.}

Deskripsi responden berdasarkan pekerjaan dapat dilihat pada Gambar 3. berikut :

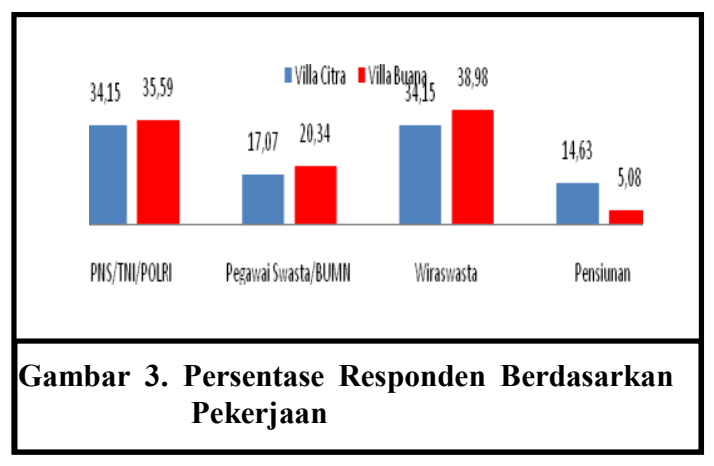


Berdasarkan Gambar 3. dapat diketahui dari 100 responden pada Villa Citra sebanyak $34,15 \%$ responden bekerja sebagai PNS/TNI/POLRI dan sebagai Wiraswasta. Sedangkan pada Villa Buana responden paling banyak bekerja sebagai Wiraswasta yaitu sebanyak 38,98 \% sedangkan yang bekerja sebagai PNS/TNI/POLRI sebanyak 35,59\%.

Deskripsi Responden Berdasarkan Pendapatan.

Deskripsi responden berdasarkan pendapatan dapat dilihat pada Gambar 4. berikut:

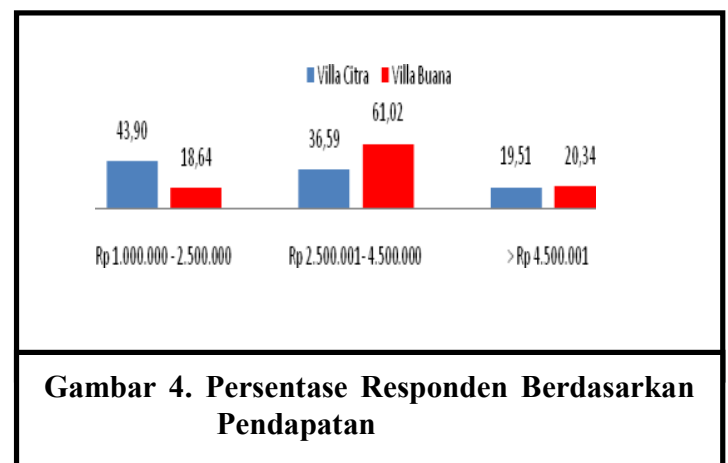

Berdasarkan Gambar 4. dapat diketahui dari 100 responden pada Villa Citra responden yang paling banyak memiliki pendapatan sekitar Rp. 1.000.000-2.500.000 yaitu sebanyak 43,90\% sedangkan pada Villa Buana sebanyak 61,02\% memiliki pendapatan rata-rata sebanyak $\mathrm{Rp}$. 2.500.000,--4.500.000,-

\section{Deskripsi Responden Berdasarkan Pengeluaran}

Deskripsi responden berdasarkan pengeluaran dapat dilihat pada Gambar 5 berikut:

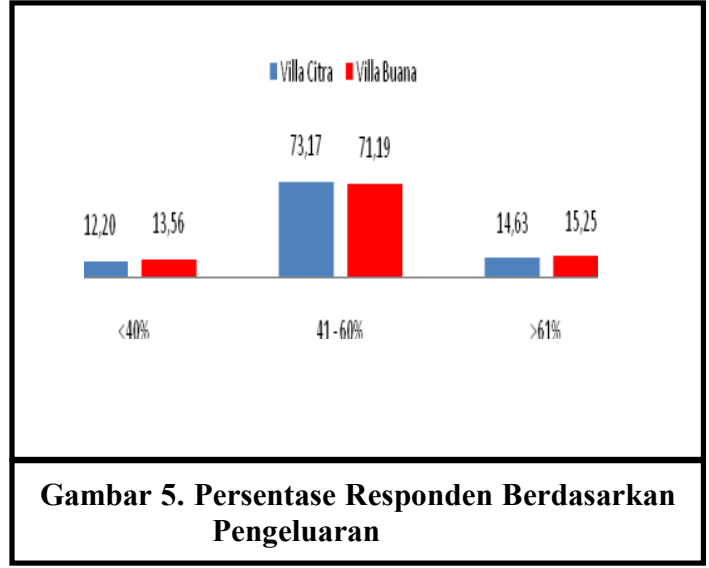

Berdasarkan Gambar 5 dapat diketahui dari 100 responden memiliki pengeluaran ratarata yang hampir sama pada penghuni Villa Citra 73,17\% dan pada Villa Buana Gardenia 71,19 \% yaitu rata-rata pengeluaran sebesar 41-60 \%.

\section{Deskripsi Responden Berdasarkan Jumlah} Anggota Keluarga

Deskripsi responden berdasarkan jumlah anggota keluarga dapat dilihat pada Gambar 6 berikut:

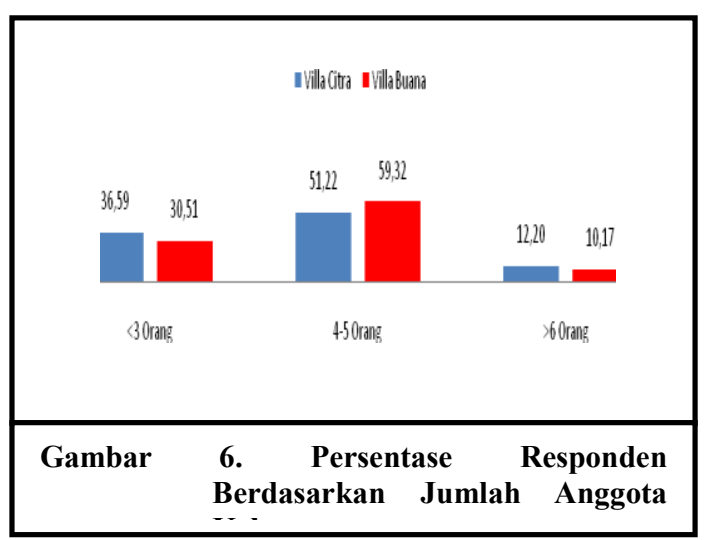

Berdasarkan Gambar 6. dapat diketahui dari 100 responden rata-rata jumlah anggota keluarga sebanyak 4-5 orang. Pada Villa Citra sebanyak 51,22 \% sedangkan pada Villa Buana Gardenia 59,32\%. 
Deskripsi Responden Berdasarkan ukuran/Type Rumah

Deskripsi responden berdasarkan Ukuran/Type Rumah dapat dilihat pada Gambar 7 berikut:

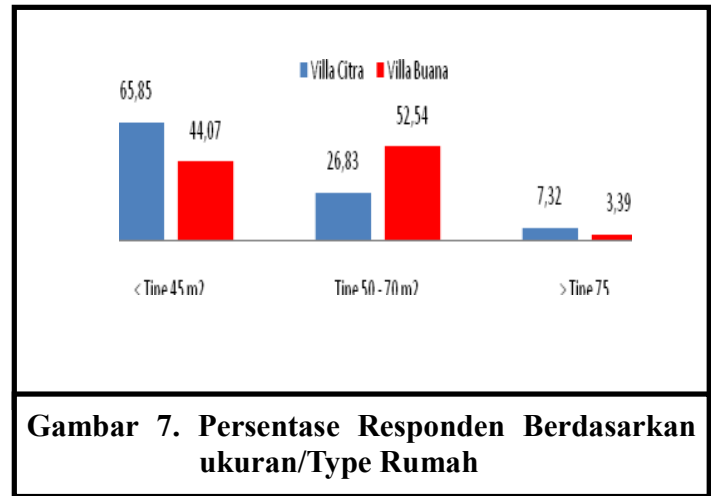

Berdasarkan Gambar 7. dapat diketahui dari 100 responden yang paling banyak memilih ukuran/type rumah sebesar $<$ Tipe $45 \mathrm{~m} 2$ sebanyak 65,85 \% pada Villa Citra dan 44,07\% pada Villa Buana Gardenia.

\section{Deskripsi Responden Berdasarkan Status} Kepemilikan

Deskripsi responden berdasarkan status kepemilikan dapat dilihat pada Gambar 8 . Berikut:

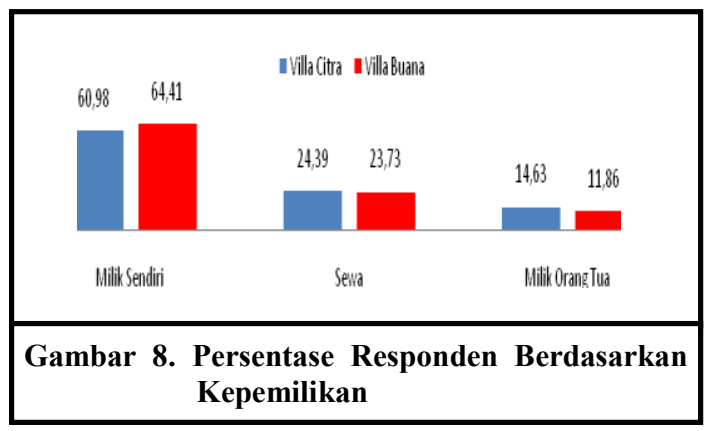

Berdasarkan Gambar 8 dapat diketahui dari 100 responden bahwa rata-rata responden pada Villa Citra dan Villa Buana berdasarkan status kepemilikan adalah milik pribadi atau milik sendiri. Sebanyak 60, $98 \%$ pada Villa Citra dan sebanyak 69,41 \% pada Villa Buana Gardenia.

\section{Deskripsi Responden Berdasarkan Lama}

\section{Menempati}

Deskripsi responden berdasarkan lama menempati dapat dilihat pada Gambar 9 berikut:

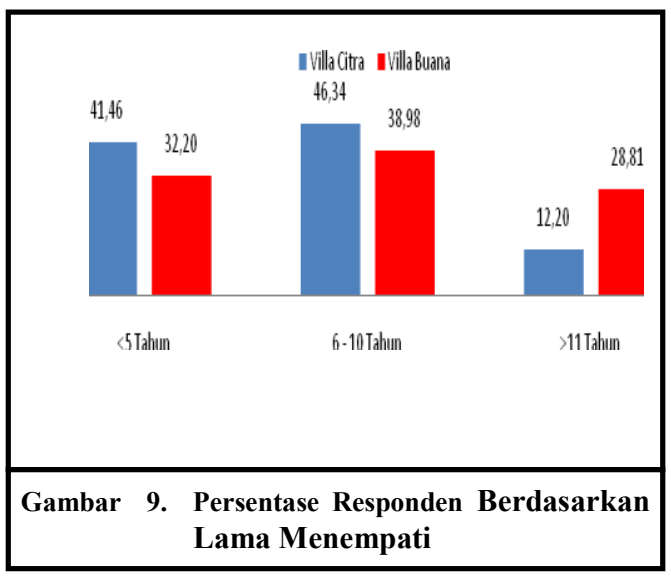

Berdasarkan Gambar 9 dapat diketahui dari 100 responden berdasarkan lama menempati yaitu paling lama rata-rata 6-10 tahun. Sebanyak 46,43\% pada Villa Citra dan sebanyak 39,98\% pada Villa Buana Gardenia.

\section{KESIMPULAN DAN SARAN}

\section{Kesimpulan}

Berdasarkan hasil penelitian dan analisis sebagaimana yang telah di kemukakan sebelumnya, maka dapat kesimpulan sebagai berikut:

1. Dari 100 responden menepati perumahan Villa Citra 39,02\% usia $<30$ Tahun dan $26,83 \%$ usia $>51$ tahun sedangkan di perumahan Villa Buana 42,37\% dimtempati usia 31 - 40 Tahun. Kedua perumahan tersebut yang menepati latar belakang pendidikan D3/S1 yaitu: 60,98\% 
Villa Citra dan 67,80\% Villa Buana. Di tinjau dari pekerjaan kedua perumahan tersebut didominasi pekerja PNS/TNI/POLRI mencapai 34,15\% dan $35,59 \%$ serta wiraswasta $34,15 \%$ dan $38,98 \%$.

2. Dari analisa diatas bahwa penghasilan Rp. $1.000 .000 \quad-\quad 2.500 .000 \quad$ memilih perumahan Villa Citra karena pegaruh faktor jarak dengan pusat Perkota sekitar 3,5 km. sedangkan Villa Buana jarak dengan pusat Perkotaan sekitar 5,5 Km. Penghasilan Rp. 2.500.001- 4.000.000 mencapai $61,02 \%$ yang penepati perumahan Villa Buana.

\section{Saran}

Berdasarkan hasil penelitian ini, penulis menyarankan beberapa hal sebagai berikut :

1. Perlunya dilakukan penelitian tentang preferensi konsumen dalam memilih perumahan dengan jumlah dan lokasi pengambilan sampel yang lebih bervariasi, sehingga dapat member informasi yang lebih akurat

2. Diharapkan penelitian ini dapat dikembangkan lebih lanjut terutama meneliti kembali faktor-faktor lain.

\section{DAFTAR PUSTAKA}

Arikunto, S. (2010). Prosedur Penelitian. Jakarta: Penerbit Rineka Cipta.

Badan Pusat Statistik. (2013). Banda Aceh Dalam Angka. Banda Aceh.

Bourne, Larry S. \& Simmons, James W. (1978). Systems of Cities: Reading on Structure, Growth and Policy. Oxford
University Press.

Budihardjo, E. (1987). Percikan Masalah Arsitektur Perumahan Perkotaan. Jakarta: Gajah Mada University Press. Budihardjo, E. (1998). Sejumlah Masalah Permukiman Kota. Bandung: Alumni.

Budihardjo, E. (2009). Perumahan \& Permukiman di Indonesia. Bandung: Alumni.

Dillon, W.R and M. Goldstein. (1984). Multivariate Analysis, Method and Application. New York: John Wiley \& Sons.

Golledge, R.G \& Stimson, R.J. (1987). Analytical Behavioral Geography. Croom Helm. Michigan University.

Hamid, F. (2009). Kamus Ilmiah Populer Lengkap. Surabaya: Appolo.

Knox, P. (1989). Urban Social Geography. Longman Scientific \& Technical.

Koentjaraningrat. (1993). Metode-Metode Penelitian Masyarakat. Jakarta: PT. Gramedia Pustaka Utama.

Morris Earl W. \& Winter Mary. (1978). Housing, Family and Society. John Willey \& Sons, Inc, New York.

Nurhadi, I. (2004). Preferensi Masyarakat dalam Memilih Perumahan Perkotaan Di Kota Tanggerang (Studi kasus Perumahan Banjar Wijaya, Poris Indah dan Perumnas IV), Tesis, Universitas Diponegoro, Semarang. Rapoport, A. (1976). Human Aspects of Urban Form. Pergamon Press.

Roistacher, E. (1977). Race and Home Ownership: Is Discrimination 
Disappearing?. California: Urban

Institut.

Suryani, T. (2008). Perilaku Konsumen

(Implikasi Pada Pemasaran).

Yogyakarta: Graha Ilmu.

Turner, J.F.C. (1982). Housing by People:

Towards Autonomy in Building

Environments. London: Marios Boyars

Van Zanten, W. (1994). Statistik Untuk Ilmu-

ilmu Sosial. Jakarta: PT. Gramedia

Pustaka Utama.

Yeaters, M. \& Garner, B. (1980). The North American City. New York: Harper \& Row, Publisher.

- How to cite this paper :

Mawardi, E., \& Rinaldy, R. (2019). Persepsi dan Motivasi Dalam Memilih Perumahan (Studi Kasus: Perumahan Villa Citra dan Villa Buana Garden). Jurnal Teknik Sipil Unaya, 5(2), 49-58 